\title{
PRIMARY PELVIC HYDATID CYST IN A PATIENT WITH PREVIOUS TOTAL ABDOMINAL HYSTERECTOMY AND BLATERAL SALPINGO-OOPHORECTOMY
}

\author{
F. Suat DEDE $M D^{\circ}$, Muberra KOÇAK, $M D^{\circ}$, \\ Nilgün OZTÜRK, $M D^{*}$, Berna DILLBAZ, $M D^{\text {me }}$
}

\section{ÖZET}

ÖNCEDEN TOTAL ABDOMINAL HISTEREKTOMI VE BILATERAL SALFINGO-OOFEREKTOMİ YAPILMIS HASTADA PRIMER PELVIK HIDADIT KisT

Primer hidadit kist hastalığ̊ değişik semptomlarla seyreden az görülen bir hastaliktır. Biz uterus ve overleri cerrahi olarak çkartılmış bir hastadaki primer pelvic hidadit hastalığı takdim ediyoruz. Kistin total eksizyonucerrahi laparoskopi ile yapılmıştır. Cerrahi sonrası hastaya yüksek doz albendezol uygulanmıstır. Radyolojik ve sonografik takiplerinde tam rezolusyon saptanmıştur. Özellikle endemic bölgelerde pelvic kitlelerin ayırıcı tanısinda hidadit hastalık akla gelmelidir.

Anahtar Kelimeler: Pelvik hidadit hastallk

\section{ABSTRACT}

Primary pelvic hydatid disease is a rare condition presenting with various symptoms. We report a case of primary pelvic hydatid disease in a patient whose uterus and ovaries were removed surgically. Total excision of the cyst was performed by operative laparoscopy. Postoperative period was uneventful and the patient was treated with high doses of albendazole. Follow-up radiologic and sonographic investigation showed complete resolution, with no other diseased site. Hydatid disease should be considered in the differential diagnosis of pelvic masses especially in the endemic regions.

Key Words: Pelvichydatiddisease

\section{Introduction}

Hydatid cystic disease is an infection of sheep and cattle caused by the larval form of Echinococcus granulosus, excreted by the canine definitive hosts. Human hydatid disease is acquired by ingestion of food contaminated with the eggs of the parasite. Although human hydatid disease may affect any part of the body, the liver, lungs and bones are affected most often.

The female reproductive system is a rare site for hydatid disease and primary pelvic involvement is an extreme rarity(1). Although there are few reports of hydatid disease involving pelvic structures like uterus(2). ovaries(3) and fallopian tubes(4), there is little evidence that primary hydatid cysts exists in cases whose pelvic structures were surgically removed.

\section{Case Report}

A 46-year-old multiparous woman was referred to the endoscopic surgery unit for a cystic mass in her pelvis. The patient reported

\footnotetext{
- Instructor in Obstetrics and Gynecology

- Resident in Obstetrics and Gynecology

-. Associate Professor of Obstetrics and Gynccology
}

Department of Gynecologic Endoscopy, Social Insurance Association Ankara Maternity and Women's Health Teaching Hospital, Ankara. 
a 16-month history of pelvic surgery (total abdominal hysterectomy and bilateral salpingo-oophorectomy) for uterine lejomyoma. After the surgery, the postoperative period was uneventful and she was remained symptomless for fourteen months. Two months before her admission to the hospital, she felt a deep vague pain in her pelvis and during the control; a pelvic cystic mass was diagnosed.

Her pelvic examination revealed a tense, cystic mass behind the vaginal vault, in the middle line. On sonographic examination, an anechoic, uniloculated cystic mass, $53 \times 50 \mathrm{~mm}$ in size was determined (Figure 1). No other pathological findings were observed in the pelvis. Her laboratory findings were within normal limits including chest $\mathrm{x}$-ray, abdominal sonography, tumor markers, liver and renal function tests.

Operative laparoscopy was performed and a $5 \mathrm{~cm}$ cystic mass lying between the bladder, right paracolic space and vaginal vault was observed. Total excision of the cyst was performed and the frozen section revealed a hydatid cyst. High doses of albendazole (10 $\mathrm{mg} / \mathrm{kg}$ ) initialized on the second postoperative day and continued for three months. Histologic examination of the cyst showed a pericyst composed of hyalinized connective tissue. Inside the cyst, chitinious layers composed of basophilic laminars and scolices were observed, confirming the diagnosis (Figure 2). The patient was discharged on the third postoperative day. Follow-up radiologic and sonographic investigation showed complete resolution, with no other diseased site.

\section{Discussion}

Primary pelvic hydatid disease is a rare condition and primary involvement of uterus, ovaries and fallopian tubes have been reported $(2,4)$. It may cause pressure on the adjacent tissues and may be a reason for pelvic pain. In addition, infertility, abstructive uropathy, foot drop or obstetric problems were reported in cases of pelvic echinococcosis $(5,8)$.

In patients with a history of total abdominal hysterectomy and bilateral salpingo-oophorectomy, pelvic cystic masses are thought to be pseudocysts that are secondary to pelvic adhesions or cysts that are originating from non-gynecologic sites. In the present report of case, the cyst capsule was well-defined with sonography and the typical sonographic presentation of a pseudocyst was not observed.

Operative laparoscopy was the treatment option for the pelvic cystic mass in this patient and successful excision of the cyst resulted in complete recovery from the pelvic pain after three months of follow-up. The percutaneous technique may be a promising management option in hydatid disease but it has limitations in pelvic masses. Not only the diagnosis but also the treatment is facilitated by magnetic resonance imaging, computed tomography and ultrasonography.

In conclusion, the gynecologists should be aware of the possibility of hydatid disease, especially in the endemic areas, when a cystic mass is found in the pelvis. We conclude that echinococcus granulosus can affect any organ in the body and a high suspicion of the disease is justified in the endemic regions. Moreover, medical treatment should precede and follow the surgical intervention.

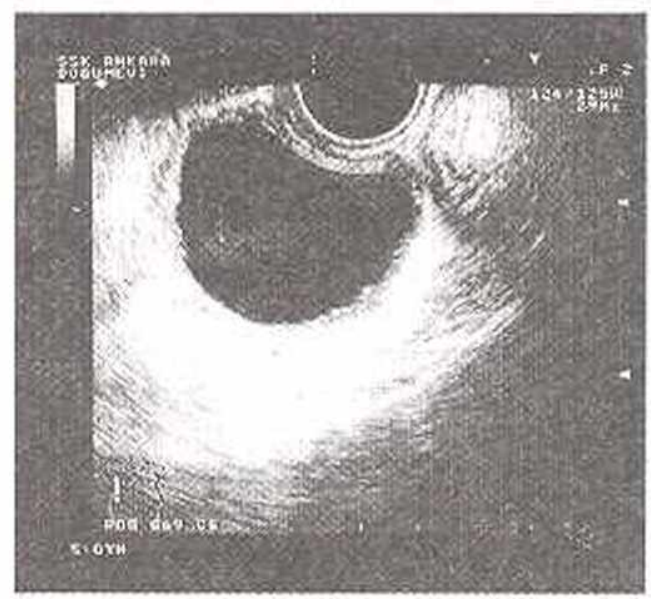

Figure 1: Transvaginal sonographic apjearance of the pelvic hydatid cyst.

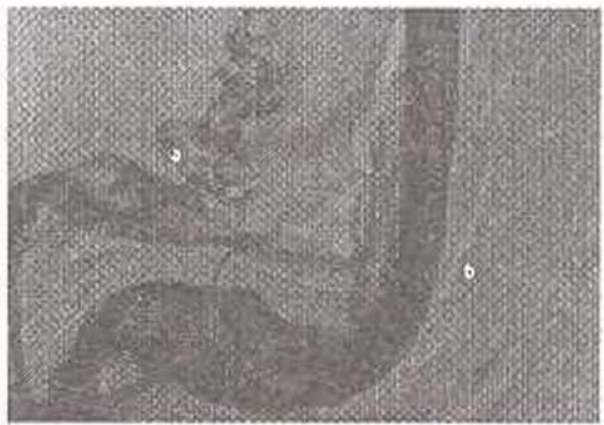

Figure 2: Hydatid cyst composed of an inner germinal layer (a), and an outer fibrous laminated layer (b). 


\section{REFERENCES}

1. Rahman MS, Rahman J, Lysikiewicz. A. Obstetrical and gynaccological presentations of hydatid disease. Br J Obstet Gynaecol. 1982; 89: 665-670.

2. Basgul A, Kavak ZN, Gokaslan H, Kullu S, Hydatid cyst of the uterus, Infect Dis Obstet Gynecol. 2002; 10: 67-70.

3. Aksu MF, Budak E, Ince U, Aksu C. Hydatid cyst of the ovary. Arch Gynecol Obstet. 1997; 261: 51-3.

4. Laghzaoui M, Aderdour M, Bouhya S, Zinoun N. Hermas S, Aderdour M. Hydatic cyst of the fallopian tube: a case report. J Gynecol Obstet Biol Reprod. 2002; 31: 390-2.

5. Abd-el-Maeboud KH. Hydatid cyst of Morgagni: any impact on fertility? J Obstet Gynaecol Res 1997; 23:427-31.

6. Seenu V. Misra MC. Tiwari SC, Jain R, Chandrashekhar C. Primary pelvic hydatid eyst presenting with obstructive uropathy and renal failure. Postgrad Med J, 1994; 70; 930-2.

7. Hassan FO, Shannak A. Primary pelvic hydatid cyst: an unusual cause of sciatica and foot drop. Spine. 2001 Jan $15 ; 26(2): 230-232$.

8. Dede S, Dede H, Caliskan E, Demir B. Recurrent pelvic hydatid cyst obstructing labor, with a concomitant hepatic primary. A case report. J Reprod Med. 2002; 47: 164.6. 